\title{
PENINGKATAN PRESTASI DAN MOTIVASI BELAJAR PPKn SISWA KELAS VIII A SMP NEGERI 2 GEDANGSARI - GUNUNGKIDUL MELALUI PEMBELAJARAN GROUP INVESTIGATION Ismiyati \\ SMP Negeri 2 Gedangsari - Gunungkidul
}

\begin{abstract}
ABSTRAK
Penelitian ini berangkat dari permasalahan dalam proses pembelajaran dan hasil belajar yang terjadi di kelas VIII A SMP Negeri 2 Gedangsari pada mata pelajaran PPKn. Proses pembelajaran tidak kondusif (siswa tidak fokus, berbicara dengan teman selama pembelajaran, tidak memerhatikan penjelasan guru). Prestasi belajar yang diperoleh siswa cenderung rendah (rata-rata 71,94 dari KKM 75). Selain itu, dari 34 siswa, hanya 10 orang siswa yang memenuhi ktiteria KKM. Bertolak dari permasalahan tersebut, tujuan penelitian ini adalah untuk meningkatkan motivasi belajar siswa yang diharapkan akan berdampak pada peningkatan prestasi belajar siswa. Upaya ini dilakukan dengan cara mengganti model pembelajaran yang konvensional dengan pembelajaran yang inovatif, yaitu pembelajaran kooperatif tipe Group Investigation. Jenis penelitian ini termasuk Penelitian Tindakan Kelas yang menggunakan model Kemmis dan Taggart. Pengumpulan data dilakukan dengan teknik tes (untuk prestasi belajar), dan pedoman observasi (untuk motivasi belajar). Data yang terkumpul dianalisis dengan teknik analisis deskriptif. Hasil penelitian menunjukkan terjadi peningkatan motivasi belajar dari pra siklus ke siklus I dan siklus II. Rata-rata motivasi belajar siswa meningkat menjadi 32 pada siklus I, dan meningkat lagi menjadi 41 pada siklus II. Sedangkan prestasi belajar juga senantiasa mengalami peningkatan. Pada siklus I, rata-rata nilai meningkat menjadi 79,91 dengan ketuntasan sebanyak 26 orang. Sedangkan pada siklus II, rata-rata nilai meningkat menjadi 89,59 dengan ketuntasan sebanyak 32 siswa. Oleh karena itu dapat disimpulkan bahwa penggunaan pembelajaran Group Investigation dapat meningkatkan motivasi belajar dan prestasi belajar siswa pada mata pelajaran PPKn.
\end{abstract}

Kata kunci: Group Investigation, Motivasi Belajar, Prestasi Belajar

\section{PENDAHULUAN}

Undang-undang Nomor 20 Tahun 2003 tentang Sistem Pendidikan Nasional ini telah merumuskan secara tegas mengenai dasar, fungsi, dan tujuan Pendidikan Nasional, yaitu berdasarkan Pancasila dan Undang-Undang Dasar 


\section{Peningkatan Prestasi dan Motivasi Belajar PPKn Siswa Kelas VIII A SMP N 2}

Gedangsari - Gunungkidul...(Ismiyati)

Negara RI Tahun 1945, sedang fungsinya mengembangkan kemampuan dan membentuk watak serta peradaban bangsa yang bermartabat dalam rangka mencerdaskan kehidupan bangsa.

Tujuan pendidikan nasional adalah mengembangkan potensi peserta didik agar menjadi manusia yang beriman dan bertaqwa kepada Tuhan Yang Maha Esa, berakhlak mulia, berilmu, cakap, kreatif, dan menjadi warga negara demokratis serta bertanggung jawab. Bertitik tolak dasar, fungsi, dan pendidikan nasional tersebut menjadi jelas bahwa manusia Indonesia berhak dibentuk melalui proses pendidikan bukan sekedar manusia berilmu pengetahuan semata tetapi sekaligus membentuk manusia Indonesia yang berkepribadian sebagai warga negara Indonesia demokratis dan bertanggung jawab.

Mata pelajaran Pendidikan Pancasila dan Kewarganegaraan merupakan pelajaran yang memfokuskan pada pembentukan karakter dan kesadaran pribadi pada setiap warga negaranya agar mampu melaksanakan hak-hak dan kewajibannya sebagai warga negara. Tujuan dari pendidikan kewarganegaraan adalah mendidik siswa agar dapat menjadi warga negara yang baik, cerdas, terampil dan berkarakter sebagaimana yang diamanatkan oleh Pancasila dan Undang-Undang Dasar Negara RI Tahun 1945.

Pendidikan Pancasila dan Kewarganegaraan mempunyai peranan sangat penting untuk mengembangkan dan melestarikan nilai-nilai luhur dan moral yang sudah berakar pada budaya bangsa Indonesia yang diharapkan dapat mewujutkan dalam perilaku kehidupan sehari-hari siswa, baik sebagai individu maupun sebagai anggota masyarakat.

Pada hakekatnya kegiatan belajar mengajar adalah suatu proses interaksi atau hubungan timbal balik antara guru dan siswa dalam satuan pembelajaran. Guru sebagai salah satu komponen dalam proses belajar mengajar merupakan pemegang peran yang sangat penting. Guru bukan hanya sekedar penyampai materi saja, tetapi lebih dari itu guru dapat dikatakan sebagai sentral pembelajaran.

Sebagai pengatur sekaligus pelaku dalam proses belajar mengajar, gurulah yang mengarahkan bagaimana proses belajar mengajar itu dilaksanakan. Karena itu guru harus dapat membuat suatu pengajaran menjadi lebih efektif juga menarik sehingga bahan pelajaran yang disampaikan akan membuat siswa merasa senang dan merasa perlu untuk mempelajari bahan pelajaran tersebut.

Berhasilnya tujuan pembelajaran ditentukan oleh banyak faktor di antaranya adalah faktor guru dalam melaksanakan proses belajar mengajar, karena guru secara langsung dapat memengaruhi, membina dan meningkatkan kecerdasan serta keterampilan siswa. Untuk mengatasi permasalahan di atas dan guna mencapai tujuan pendidikan secara maksimal, peran guru sangat penting dan diharapkan guru memiliki model mengajar yang baik dan mampu memilih model 
pembelajaran yang tepat dan sesuai dengan konsep-konsep mata pelajaran yang akan disampaikan.

Peningkatan hasil belajar akan tercapai apabila terjadi pembelajaran yang bermakna, yakni pembelajaran yang mampu melibatkan secara aktif peserta didik baik fisik, mental, intelek, dan emosional.Hal ini tergantung pada kemampuan guru di dalam mengajar. Guru akan memiliki kompetensi mengajar, jika guru memiliki pemahaman dan penerapan secara taktis berbagai model belajar mengajar serta hubungannya dengan belajar, disamping kemampuan-kemampuan lain yang menunjang. Beberapa pertimbangan yang harus dilihat guru dalam menentukan model pembelajaran yang akan dipakai, antara lain, adalah: tujuan, peserta didik, bahan pelajaran, fasilitas, situasi,partisipasi, guru, kebaikan dan kelemahan metode tertentu (Situmorang, Suparman, dan Susilana, 2004).

Dari hasil pengamatan mengajar selama ini, khususnya siswa kelas VIII A SMP Negeri 2 Gedangsari, Gunungkidul hasil proses belajar mengajar menunjukkan bahwa sebagian siswa kurang memperhatikan, ramai sendiri pada saat siswa menerima pelajaran PPKn. Sehingga nilai rata-rata mata pelajaran PPKn rendah, yaitu hanya 71,94 (dibawah KKM yaitu 75,00). Dari 34 siswa yang ada, sebanyak 24 orang (70,5\%) tidak dapat mencapai KKM, dan hanya 10 orang $(29,5 \%)$ yang dapat mencapai KKM tersebut. Kenyataan menyatakan bahwa mengajar dengan model ceramah dan tanya jawab dirasa membosankan disamping kurangnya motivasi belajar yang disebabkan siswa kurang menyadari pentingnya pendidikan dan keadaan geografis yang kurang memungkinkan yaitu di daerah pengunungan.

Dari keadaan tersebut di atas, penulis merasa perlu untuk mencoba menerapkan cara lain yaitu mengajar dengan model Group Investigation yang diterapkan pada kelas VIII A. Dengan menggunakan model Group Investigation diharapkan dapat meningkatkan prestasi belajar dan motivasi belajar siswa terhadap mata pelajaran PPKn.

Setelah mengetahui permasalahannya, peneliti mencoba merumuskan masalah dalam penelitian ini sebagai berikut: 1) Apakah dengan penerapan model Group Investigation dapat meningkatkan prestasi belajar PPKn siswa kelas VIIIA SMP Negeri 2 Gedangsari, Gunungkidul? 2) Apakah dengan penerapan model Group Investigation dapat meningkatkan motivasi belajar PPKn siswa kelas VIII A SMP Negeri 2 Gedangsari, Gunungkidul?

\section{Tujuan dan Manfaat Penelitian}

Berdasarkan rumusan masalah yang telah dikemukakan, maka tujuan yang hendak dicapai dalam penelitian ini adalah: 1). Untuk meningkatkan prestasi belajar PPKnmelalui penggunaan modelGroup Investigationdi kelas VIII A SMP 
Peningkatan Prestasi dan Motivasi Belajar PPKn Siswa Kelas VIII A SMP N 2

Gedangsari - Gunungkidul...(Ismiyati)

Negeri 2 Gedangsari, Gunungkidul, dan 2) Untuk meningkatkan motivasi belajar PPKn melalui penggunaan model Group Investigationdi kelas VIII A SMP Negeri 2 Gedangsari, Gunungkidul.

Penelitian ini diharapkan dapat bermanfaat bagi siswa, guru, dan lembaga pendidikan:

1) Manfaat bagi siswa.Implementasi model Group Investigation ini diharapkan bermanfaat untuk meningkatkan prestasibelajar dan motivasi belajar siswa. 2) Manfaat bagi guru yaitu dapat mengembangkan kreatifitasnya sehingga diperoleh model belajar mengajar yang lebih efektif. 3) Manfaat bagi sekolah/lembaga pendidikan yaitu memberi informasi pada sekolah/lembaga pendidikan tentang pentingnya menggunakan model pembelajaran yang tepat agar terjadi peningkatan prestasi belajar dan motivasi belajar siswa.

\section{KAJIAN PUSTAKA}

Menurut Slameto (2010:2), belajar merupakan suatu proses usaha yang dilakukan seseorang untuk memeroleh suatu perubahan tingkah laku yang baru secara keseluruhan, sebagai hasil pengalamannya sendiri dalam interaksi dengan lingkungannya. Sedangkan Syah (2008:90-91) berpendapat bahwa belajar adalah suatu perubahan yang terjadi dalam diri organisme (manusia dan hewan) disebabkan oleh pengalaman dapat memengaruhi tingkah laku organisme. Perubahan yang ditimbulkan oleh pengalaman tersebut baru dapat dikatakan belajar apabila memengaruhi organisme. Perubahan kemapuan bereaksi yang relative permanen sebagai hasil latihan yang diperkuat. Dalam definisi ini terdapat empat macam istilah yang esensial dan perlu disoroti untuk memahami proses belajar, yakni: Relativelypermanent (yang secara umum menetap), Respons Potentiality (kemampuan bereaksi), Reinforce (penguatan), dan Practice (praktik atau latihan).

Hakim (2001:1) mengemukakan bahwa belajar adalah suatu proses perubahan di dalam kepribadian manusia, dan perubahan tersebut ditampakan dalam bentuk peningkatan kualitas dan kuantitas tingkah laku seperti peningkatan kecakapan, pengetahuan, sikap, kebiasaan, pemahaman, ketrampilan, daya pikir, dan lain-lain. Gulo (2002:8) menjelaskan bentuk-bentuk perubahan tingkah laku yang dialami akibat belajar, yaitu tingkah laku dalam berpikir, bersikap, dan berbuat. Dengan demikian, dapat disarikan bahwa keberhasilan proses belajar dapat dilihat dari perubahan bentuk-bentuk tingkah laku tersebut.

Pengertian-pengertian belajar nampak merujuk pada dampak dari proses belajar. Untuk mengoptimalkan dampak tersebut, maka perlu ada prinsip-pinsip belajar yang memungkinkan proses belajar dapat dilaksanakan secara efektif. Sukmadinata (2005:165-167) mengungkapkan prinsip-prinsip sebagai berikut: (1) 
Belajar merupakan bagian dari perkembangan; (2) Belajar berlangsung seumur hidup; (3) Keberhasilan belajar dipengaruhi oleh faktor-faktor bawaan, faktor lingkungan, kematangan serta usaha dari individu sendiri; (4) Belajar mencakup semua aspek kehidupan; (5) Kegiatan belajar berlangsung pada setiap tempat dan waktu; (6) Belajar berlangsung dengan guru atau tanpa guru; (7) Belajar yang berencana dan disengaja menuntut motivasi yang tinggi; (8) Perbuatan belajar bervariasi dari yang paling sederhana sampai dengan yang kompleks; (9) Dalam belajar dapat terjadi hambatan-hambatan; (10) Untuk kegiatan belajar tertentu diperlukan adanya bantuan dan bimbingan dari orang lain. Prinsip belajar yang dikemukakan tersebut menyiratkan bahwa belajar dipengaruhi oleh berbagai faktor.

Berbagai faktor-faktor yang ada dapat dikelompokkan menjadi dua kelompok berdasarkan asalnya, yaitu kelompok faktor intern, dan kelompok faktor ekstern. Kelompok faktor intern adalah faktor-faktor dari dalam diri pembelajar yang berpengaruh pada belajarnya. Sedangkan kelompok faktor ekstern adalah faktor-faktor dari luar diri pembelajar. Terdapat berbagai faktor yang ada dalam kelompok intern dan ekstern. Namun, faktor yang secara langsung berpengaruh pada belajar dari kelompok intern, salah satunya adalah motivasi. Sedangkan faktor ekstern yang secara langsung berpengaruh pada belajar adalah strategi mengajar guru.

\section{Prestasi Belajar}

Prestasi belajar sering disamakan dengan hasil belajar. Hal ini dikarenakan kedua konsep tersebut merupakan tujuan akhir dari kegiatan belajar. Para ahli memiliki pandangan masing-masing dalam mendefinisikan kedua konsep tersebut. Secara etimologi prestasi berasal dari bahasa Belanda yaitu prestase yang berarti hasil usaha. Dengan demikian prestasi belajar merupakan hasil dari usaha belajar. Sub bab ini akan menyajikan beberapa definisi hasil belajar dan prestasi belajar berdasarkan berbagai pustaka yang telah dikaji.

Tafsir (2008:34-35) berpendapat bahwa prestasi belajar adalah hasil akhir yang diharapkan dapat dicapai setelah seseorang belajar. Hasil belajar atau bentuk perubahan tingkah laku yang diharapkan itu merupakan suatu target atau tujuan pembelajaran yang meliputi 3 (tiga) aspek yaitu: (1) Tahu, mengetahui (knowing), (2) Terampil melaksanakan atau mengerjakan yang ia ketahui itu (doing) dan, (3) Melaksanakan yang diketahui itu secara rutin dan konsekwen (being).

Hasil belajar adalah perubahan perilaku peserta didik akibat belajar (Purwanto, 2011:46). Secara teknis, perubahan perilaku yang dimaksud disebabkan oleh penguasaan bahan yang diberikan selama proses belajar. Selanjutnya Sudjana (2003:3) menyatakan bahwa hasil belajar sebagai perubahan 
tingkah laku yang mencakup bidang kognitif, afektif, dan psikomotorik yang dimiliki oleh siswa setelah menerima pengalaman belajar. Pengertian menurut Sudjana tersebut nampak menyempurnakan pengertian menurut Purwanto, di mana perubahan perilaku mencakup aspek kognitif, afektif, dan psikomotorik. Sedangkan Hamalik (2011:155) menyatakan bahwa hasil belajar sebagai terjadinya perubahan tingkah laku pada diri seseorang yang dapat diamati dan diukur bentuk pengetahuan, sikap dan keterampilan. Pengertian tersebut menunjukkan indikator empiris dari hasil belajar, yaitu pengetahuan (knowledge), sikap (atitude), dan keterampilan (skills). Jika dikaji lebih lanjut, pengetahuan yang dikemukakan oleh Hamalik merupakan istilah lain dari konsep kognitif menurut Sudjana. Sementara sikap merupakan istilah lain dari afektif, dan keterampilan sebagai aspek psikomotorik.

Supaya indikator hasil belajar dapat dijabarkan secara lebih operasional, maka diperlukan dimensi hasil belajar. Salah satu konsep dimensi hasil belajar dikemukakan oleh Grondlund (Satmoko, 1999:26-27) di mana dimensi hasil belajar terdiri dari: (1) Pengetahuan terminologi, fakta khusus, konsep dan prinsip, metode dan prosedur; (2) Pengertian: konsep dan prinsip, metode dan prosedur, materi tertulis, grafik, gambar, peta, dan data bilangan; (3) Aplikasi informasi aktual, konsep dan prinsip, metode dan prosedur, keterampilan dalam pemecahan masalah; (4) Keterampilan berpikir: kritis, ilmiah; (5) Keterampilan umum: laboratorium, bertindak, berkomunikasi, konseptual, sosial; (6) Sikap: sosial, ilmiah; (7) Minat: pribadi, pendidikan dan kejuruan; (8) Apresiasi: literatur, seni, musik, pencapaian sosial, dan ilmiah; (9) Penyesuaian diri: sosial dan emosional.

\section{Faktor-faktor yang Memengaruhi Prestasi Belajar}

Selain konsep hasil belajar dan indikatornya, perlu dikaji juga faktorfaktor yang memengaruhi prestasi belajar secara teoritis. Menurut Djamarah (2008:176-202) faktor-faktor yang memengaruhi proses dan prestasi belajar adalah:

- Faktor lingkungan. Faktor ini terdiri dari lingkungan alami atau lingkungan hidup dan lingkungan sosial budaya.

- Faktor instrumental. Terdiri darikurikulum, program, sarana dan fasilitas, serta guru.

- Faktor fisiologis yang terdiri dari kondisi fisiologis, dan kondisi pancaindra.

- Faktor psikologis yang terdiri dari minat, kecerdasan, bakat, motivasi dan kemampuan kognitif.

Keempat faktor tersebut sebenarnya dapat dikelompokkan lagi kedalam 2 kelompok, yaitu faktor internal (fisiologis dan psikologis), dan faktor eksternal 
(lingkungan dan instrumental). Kesimpulan ini senada dengan Astin (Heywood, 2000:123) yang menyusun model I-E-O (Inputs, Environment, dan Outcomes).

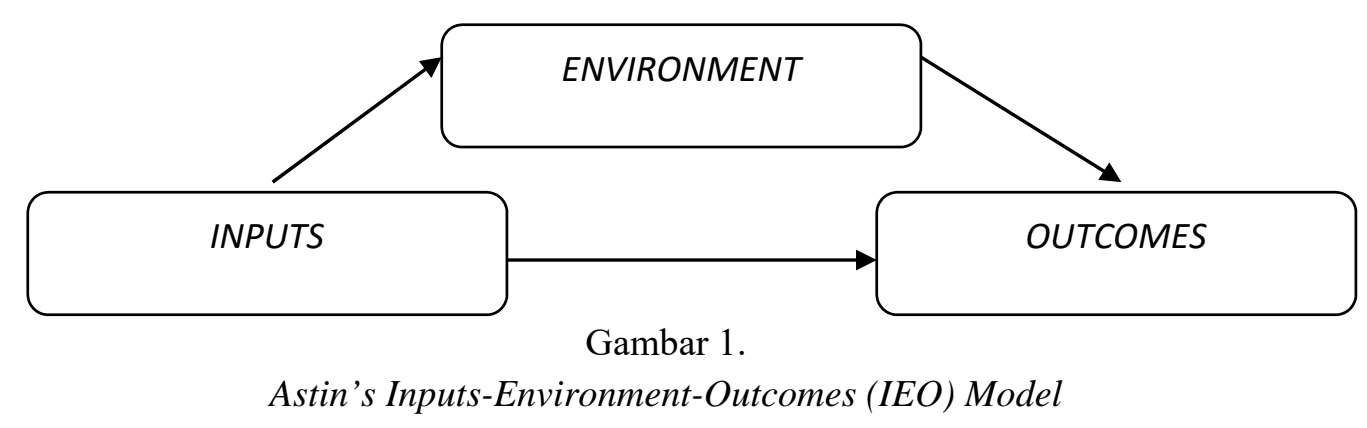

Inputs merupakan komponen yang ada dalam diri siswa atau faktor intern yang dibawa kedalam program pendidikan. Inputs dapat meliputi: informasi demografis, latar belakang pendidikan, orientasi politik, pola perilaku, tingkat aspirasi, alasan masuk sekolah, status finansial, status kecakapan, pilihan karir, jurusan atau mata pelajaran yang dipilih siswa, tujuan hidup, dan lain-lain.

Environmet dapat diterjemahkan sebagai lingkungan. Dengan demikian environment berisikan faktor-faktor eksternal yang ada diluar siswa. Faktor ini dapat terdiri dari: program, kurikulum, pengajar, fasilitas, iklim lembaga, pengajaran, gaya mengajar, teman, kelompok belajar, kegiatan ekstrakurikuler, dan afiliasi sekolah.

Sementara Outcomes merujuk pada hasil belajar siswa atau prestasi belajar siswa. Hal ini dapat dilihat dari nilai post test sebagai akibat atau hasil akhir, di mana nilai ini memiliki indikator seperti IPK, skor ujian, hasil pelajaran, tingkat penyelesaian atau yudisium, dan kepuasan pendidikan.

\section{Motivasi belajar}

Motivasi sebagai salah satu bagian dari faktor intern yang memengaruhi hasil belajar memiliki berbagai definisi. Misalnya pengertian yang dikemukakan oleh McDonald yang menyatakan bahwa motivasi adalah perubahan energi dalam diri seseorang yang ditandai dengan munculnya feeling dan didahului dengan tanggapan terhadap adanya tujuan (Sardiman, 2011:73). Munculnya motivasi dalam diri seseorang didasari adanya kebutuhan yang hendak dicapai.

Sementara itu, Maslow dalam teori hierarki kebutuhannya menyatakan bahwa manusia baru akan termotivasi untuk memenuhi suatu kebutuhan tertentu apabila kebutuhan dasar dan kebutuhan yang lebih rendah hierarkinya telah dipenuhi. Hierarki kebutuhan yang dinyatakan oleh Maslow mulai dari paling 
Peningkatan Prestasi dan Motivasi Belajar PPKn Siswa Kelas VIII A SMP N 2

Gedangsari - Gunungkidul...(Ismiyati)

dasar hingga paling lanjut sebagaimana dikutip dalam Slameto (2010: 171) adalah sebagai berikut: (1) Kebutuhan fisiologis; (2) Kebutuhan akan rasa aman; (3) Kebutuhan akan kasih sayang; (4) Kebutuhan akan penghargaan; (5) Kebutuhan akan aktualisasi diri; (6) Kebutuhan mengetahui dan mengerti; (7) Kebutuhan estetik.

Sementara itu, Lionel Robbins (Wibowo dan Priyono, 2006:119) mencirikan 4 dasar dalam kehidupan manusia, dengan berangkat dari definisi ilmu ekonomi yang dikemukakannya, yaitu: (1) Manusia memiliki kehendak untuk dipenuhi; (2) Alat (uang) untuk memenuhi kehendak tersebut terbatas; (3) Sumber yang terbatas digunakan untuk beberapa pilihan kegunaan; (4) Manusia perlu membuat pilihan. Konsep yang dikemukakan oleh Robbins bermuara pada konsep Problem of Choice.Konsep tersebut menjelaskan bahwa manusia dihadapkan pada berbagai pilihan, dan perlu melakukan kegiatan memilih dalam kerangka kebutuhan dan alat pemuas kebutuhan.

\section{Pembelajaran Kooperatif Model Group Investigation}

Menurut Trianto (2007), pembelajaran kooperatif muncul dari konsep bahwa siswa akan lebih mudah menemukan dan memahami konsep yang sulit jika mereka saling berdiskusi dengan temannya. Siswa secara rutin bekerja dalam kelompok untuk saling membantu memecahkan masalah-masalah yang kompleks. Jadi, hakikat sosial dan penggunaan kelompok sejawat menjadi aspek utama dalam pembelajaran kooperatif. Di dalam kelas kooperatif siswa belajarbersama dalam kelompok-kelompok kecil yang terdiri dari 4-6 orang siswa yang sederajat tetapi heterogen, kemampuan, jenis kelamin, suku atau ras, dan satu sama lain saling membantu. Slavin mengemukakan bahwa belajar kooperatif adalah salah satu variasi dari metode pengajaran di mana siswa bekerja dalam kelompokkelompok kecil sehingga mereka saling membantu antara satu dengan lainnya dalam mempelajari suatu pokok bahasan.

Group Investigation merupakan salah satu bentuk model pembelajaran kooperatif yang menekankan pada partisipasi dan aktivitas siswa untuk mencari sendiri materi (informasi) pembelajaran yang akan dipelajari melalui bahan-bahan yang tersedia, misalnya dari buku pelajaran atau siswa dapat mencari memalui internet. Siswa dilibatkan sejak perencanaan, baik dalam menentukan topik maupun cara untuk mempelajarinya melalui investigasi. Tipe ini menuntut para siswa untuk memiliki kemampuan yang baik dalam berkomunikasi maupun dalam ketrampilan proses kelompok. Model Group Investigation dapat melatih siswa untuk menumbuhkan kemampuan berfikir mandiri. Keterlibatan siswa secara aktif dapat terlihat mulai tahap pertama sampai tahap akhir pembelajaran. 
Di sini guru lebih berperan sebagai konselor, konsultan, sumber kritik yang konstruktif. Peran tersebut ditampilkan dalam proses pemecahan masalah, pengelolaan kelas, dan pemaknaan perseorangan. Peranan guru terkait dengan proses pemecahan masalah berkenaan dengan kemampuan meneliti apa hakikat dan fokus masalah. Pengelolaan ditampilkan berkenaan dengan kiat menentukan informasi yang diperlukan dan pengorganisasian kelompok untuk memeperoleh informasi tersebut. Pemaknaan perseorangan berkenaan dengan inferensi yang di organisasi oleh kelompok dan bagaimana membedakan kemampuanperseorangan.

Adapun langkah-langkah dalam Model Group Investigation ini, adalah sebagai berikut: 1) Guru membagi kelas dalam beberapa kelompok heterogen, 2) Guru menjelaskan maksud pembelajaran dan tugas kelompok, 3) Guru memenggil ketua-ketua untuk satu materi tugas sehingga satu kelompok mendapat tugas satu materi atau tugas yang berbeda dari kelompok lain, 4) Masing-masing kelompok membahas materi yang sudah ada secara kooperatif berisi penemuan, 5) Setelah selesai diskusi lewat juru bicara, ketua menyampaikan hasil pembahasan kelompok, 6) Guru memberikan penjelasan singkat sekaligus memberi kesimpulan, 7) Evaluasi, dan 8) Penutup.

Kelebihan model pembelajaran model Group Investigation menurut Slavin (dalam Nizar, 2008:102) adalah sebagai berikut: 1) Pembelajaran dengan kooperatif model Group Investigation memiliki dampak positip dalam meningkatkan motivasi belajar siswa. 2) Penerapan metode pembelajaran kooperatif model Group Investigation mempunyai pengaruh positif, yaitu dapat meningkatkan motivasi belajar siswa. 3) Pembelajaran yang dilakukan membuat suasana saling bekerja sama dan berinteraksi antar siswa dalam kelompok tanpa memandang latar belakang. 4) Model pembelajaran Group Investigation melatih siswa untuk memiliki kemampuan yang baik dalam berkomunikasi dan mengemukakan pendapatnya. 5) Memotivasi dan mendorong siswa agar aktif dalam proses belajar mulai dari tahap pertama sampai tahap akhir pembelajaran.

Kelemahan pembelajaran dengan model Group Investigation menurut sumber yang sama dikemukakan bahwa model pembelajaran Group Investigation merupakan modelpembelajaran yang komplek dan sulit untuk dilaksanakan dalam pembelajaran kooperatif. Kemudian pembelajaran dengan menggunakan Group Investigation juga membutuhkan waktu yang lama.

\section{METODE PENELITIAN}

Penelitian ini dilaksanakan di SMP Negeri 2 Gedangsari, Gunungkidul khususnya kelas VIII A. Sekolah SMP Negeri 2 Gedangsari merupakan sekolah paling utara dari kabupaten Gunungkidul yang berjarak lebih kurang $50 \mathrm{~km}$ dari ibu kota kabupaten dan berbatasan dengan Kabupaten Klaten.Sekolahiniterletak di 


\section{Peningkatan Prestasi dan Motivasi Belajar PPKn Siswa Kelas VIII A SMP N 2}

Gedangsari - Gunungkidul...(Ismiyati)

desa Tegalrejo, Gedangsari, Gunungkidul.Di sebelah selatan sekolah ini pegunungan dan disebelah utara daerah datar yaitu kecamatan Bayat, kabupaten Klaten.SMP Negeri 2 Gedangsari memiliki 18 ruang kelas dengan masing-masing tingkatan 6 kelas dan rata-rata siswa 32 orang siswa.Penelitian ini akandilaksanakan pada semester I tahun ajaran 2014/2015, tepatnya pada 21 Oktober 2014 hingga 25 November 2014 (6 kali pertemuan).

Subyek penelitian adalah siswa kelas VIIIA SMP Negeri 2 Gedangsari, Gunungkidul sedangkan pelaku penelitian adalah penulis yaitu guru PPKn dibantu olehguru pengamat sekaligus sebagai observer.Penelitian dilaksanakan oleh peneliti dan guru lain.Peneliti sebagai pengajar yang melaksanakan proses belajar mengajar dengan menggunakan model Group Investigation dari siklus yang satu ke siklus yang berikutnya.Setiap siklus meliputi perencanaan, pelaksanaan,dan observasi serta refleksi sesuai model PTK menurut Kemmis dan Taggart (Taniredja, T., Pujiati, I., Nyata, 2011: 24).Penelitian ini dilakukan dengan menggunakan metode Penelitian Tindakan Kelas yang terdiri dari 2 siklus.Langkah-langkah dalam siklus penelitian terdiri dari:

- Perencanaan. Kegiatan ini terdiri dari:

a. Membuat Rencana Pelaksanaan Pembelajaran (RPP) sesuai dengan materi yang akan disampaikan. RPP disusun dengan memperhatikan masukan dari kepala sekolah maupun guru yang sesuai dengan bidangnya (MGMP tingkat sekolah). RPP digunakan sebagai acuan atau pedoman dalam melaksanakan kegiatan belajar mengajar di kelas. RPP yang digunakan dalam penelitian ini terlampir dalam lampiran penelitian ini.

b. Menyusun dan memersiapkan lembar observasi pembelajaran yang mencakup tentang partisipasi siswa.

c. Memersiapkan media pembelajaran dan Lembar Kerja Siswa.

d. Memersiapkan soal tes.

- Pelaksanaan dan observasi. Penelitian ini dilaksanakan berdasarkan panduan perencanaan yang telah disusun dan pelaksanaannya bersifat fleksibel apabila terdapat perubahan-perubahan. Selama proses pembelajaran mengajar berlangsung guru akan menyajikan materi sesuai dengan RPP yang telah disusun dan observer akan mengamati partisipasi siswa. Observasi dilaksanakan selama proses belajar mengajar berlangsung dengan melakukan pengamatan dan mencatat hasil observasi dalam lembar pengamatan yang telah dipersiapkan sebelumnya.

- Refleksi. Hasil pengamatan di diskusikan bersama antara peneliti dengan pengamat untuk mengevaluasi hasil investigasi dan permasalahanpermasalahan yang timbul untuk diadakan perbaikan-perbaikan pada siklus ke II, dan seterusnya.

Dalam pengumpulan data penulis menggunakan metode test yaitu melakukan evaluasi (postest) untuk mendapatkan data dan nilai kelas VIII A. 
Dalam melaksanakan evaluasi untuk memeroleh data penulis bekerja sama dengan guru pengamat. Kegiatannya antara lain:

- Menyusun soal test

- Menyampaikan soal tes kepada siswa untuk dikerjakan

- Menilai hasil pekerjaan dari siswa

- Memeroleh data hasil prestasi dari siswa.

- Observasi proses belajar siswa.

Dari lembar observasi dan hasil tes belajar di dapatkan data dan kemudian dilakukan langkah-langkah analisis:

- Analisis data observasi. Data yang diperoleh dalam penelitian ini yang berupa lembar observasi proses pembelajaran kemudian dihitung dan di prosentase. Dengan demikian dapat diketahui sejauh mana peningkatan yang dicapai dalam pembelajaran. Hasil analisis data observasi kemudian disajikan secara diskriptif berdasarkan hasil observasi dan refleksi.

- Analisis hasil tes belajar. Kegiatan ini dilakukan dengan cara:

a. Hasil tes belajar yang diperoleh pada akhir pertemuan ditambahkan pada skor kelompok, sehingga diperoleh nilai masing-masing siswa.

b. Nilai masing-masing siswa tersebut kemudian dirata-rata. Nilai ratarata pada siklus I, dan II dibandingkan. Apabila siklus I, dan II, selalu mengalami peningkatan maka dapat dikatan bahwa pembelajaran modelGroup Investigation dapat meningkatkan hasil belajar siswa. Indikator keberhasilan dalan penelitian ini adalah:

- Adanya peningkatan efektifitas proses pembelajaran yang ditandai dengan meningkatnya motivasi belajar siswa.

- Prestasi belajar siswa meningkat hingga 90\% siswa tuntas KKM.

\section{HASIL PENELITIAN}

\section{Deskripsi Hasil Prasiklus}

Hasil prasiklus diperoleh dari nilai ulangan harian yang telah dilaksanakan sebelumnya.Tes ini di berikan dalam bentuk soal uraian yang terdiri dari 5 soal. Rata-rata kelas yang diperoleh pada tes harian yaitu 71,94. Jumlah siswa yang tuntas KKM pada tes tersebuthanya 10 siswa atau 29,5\% dari 34 siswa. Sedangkan siswa yang belum tuntas mencapai 24 atau 70,5\%. Hasil prasiklus menunjukkan nilai tertinggi 92 dan nilai terendah 55, dengan kriteria ketuntasan minimal (KKM) 75. Ketuntasan hasil prasiklus terlihat pada tabel 1 dibawah ini. Selain hasil belajar yang buruk, proses pembelajaran juga buruk. Siswa terlihat tidak antusias dalam mengikuti pembelajaran, dan tidak banyak terlibat dalam proses belajar mengajar yang diselenggarakan. Selain itu, siswa hanya mengandalkan guru sebagai satu-satunya sumber belajar. 
Peningkatan Prestasi dan Motivasi Belajar PPKn Siswa Kelas VIII A SMP N 2

Gedangsari - Gunungkidul...(Ismiyati)

Tabel 1

Ketuntasan Prestasi Belajar Prasiklus

\begin{tabular}{|l|c|c|c|l|}
\hline No & Nilai & Jumlah Siswa & Persentase & Keterangan \\
\hline 1 & $<75$ & 24 & $70,5 \%$ & Tidak tuntas \\
\hline 2 & $\geq 75$ & 10 & $29,5 \%$ & Tuntas \\
\hline & JUMLAH & 34 & $100 \%$ & \\
\hline
\end{tabular}

Melihat permasalahan pembelajaran yang dialami kelas VIII A SMP Negeri 02 Gedangsari, maka penelitian menggunakan model pembelajaran kooperatif tipe Group Investigationdengan tujuan agar siswa melakukan diskusi, saling membantu antar teman dan semua anggota kelompok mempunyai peran dan tanggung jawab yang sama sehingga motivasi dan hasil belajar siswa pada materi selanjutnya dapat meningkat.

\section{Deskripsi Hasil Siklus I}

Pelaksanaan siklus I pada hari Selasa, 21 Oktober 2014 dan Selasa, 28 Oktober 2014 dengan menggunakan model pembelajaran Kooperatif Tipe Group Investigation. Materi yang diajarkan pada siklus ini adalah Disiplin Itu Indah. Setiap pertemuan terdiri dari 3 jam pelajaran (yang masing-masing 40 menit).

Setelah diajarkan selama 2 kali pertemuan, dilaksanakan tes dalam bentuk uraian yang berjumlah 5 soal yang dilaksanakan pada tanggal 4 November 2014 . Rata-rata nilai kelas pada tes siklus I yaitu 79,91. Berdasarkan hasil nilai yang diperoleh siswa pada siklus I dapat diketahui nilai terendah 70 dan nilai tertinggi 93. Siswa yang mencapai kriteria ketuntasan minimal yaitu 26 siswa atau 76,5\%. Sedangkan siswa yang belum mencapai kriteria ketuntasan minimal yaitu 8 siswa atau 23,5\%. Ketuntasan hasil tes siklus I terlihat pada tabel 4.2. Selain prestasi belajar, motivasi siswa juga nampak mengalami peningkatan secara kasat mata. Sedangkan berdasarkan data yang diperoleh dari instrumen pedoman observasi didapatkan bahwa rata-rata motivasi belajar siswa adalah 32. Hal ini menandakan motivasi belajar siswa cukup baik.

Tabel 2

Ketuntasan Prestasi Belajar siklus I

\begin{tabular}{|l|c|c|c|l|}
\hline No & Nilai & Jumlah Siswa & Persentase & Keterangan \\
\hline 1 & $<75$ & 8 & $23,5 \%$ & Tidak tuntas \\
\hline 2 & $\geq 75$ & 26 & $76,5 \%$ & Tuntas \\
\hline & JUMLAH & 34 & $100 \%$ & \\
\hline
\end{tabular}


Meski sudah berjalan cukup baik, nampak bahwa masih terdapat siswa yang tidak tuntas. Penyebab ketidaktuntasan pada siklus ini karena saat pembelajaran berlangsung, siswa kurang berpartisipasi di dalam kelas.Banyak diantaranya hanya diam saja dan malu bertanya kepada guru saat mengalami kesulitan. Selain itu dalam berkelompok siswa tidak aktif berdiskusi, masih didominasi oleh siswa yang pintar, kurangnya kerja sama dan tanggung jawab antar siswa. Kurangnya motivasi belajar siswa, berdasarkan pengamatan observer, motivasi siswa rendah dipengaruhi oleh kurang kerjasama antara siswa yang satu dengan lainnya. Siswa yang pintar cenderung tidak peduli dengan siswa yang kurang, tidak mau mengajari yang kurang sehingga siswa yang kurang hanya mencontek. Tahap akhir pertemuan pada siklus I ini, guru memberikan 5 soal tes uraian untuk siklus I. Banyak siswa yang berani menyontek dan berdiskusi, mereka berani jalan-jalan untuk berdiskusi, sebagian besar diantaranya adalah siswa laki-laki. Ada siswa yang hanya diam mengerjakan tes sebisa mereka dan hanya 1 soal yang kerjakan siswa tersebut tetapi masih belum benar.

\section{Perbandingan Prasiklus dan Siklus I}

Berdasarkan hasil tes prasiklus dan hasil tes siklus I dengan 5 soal uraian yang dikerjakan secara individu, diketahui masih banyak siswa yang belum mencapai KKM (kriteria ketuntasan minimal). Hasil tes yang diperoleh pada prasiklus dan siklus I masih rendah atau belum mencapai indikator kinerja dalam penelitian ini yaitu 90\% dengan KKM 75 (Kriteria ketuntasan minimal) karena pada siklus I siswa masih belum mengerti terkait model yang digunakan. Ketika kerja kelompok masih banyak siswa yang tidak berdiskusi dalam menyelesaikan soal. Mereka masih menggandalkan satu, dua siswa lainnya tetapi ketika mendapat undian untuk maju ke depan menjelaskan hasil diskusinya masih banyak yang belum mengerti jawaban yang ditulis di lembar jawaban.

Tes prasiklus dan siklus I yang telah dilaksanakan, masih banyak siswa yang belum mencapai nilai KKM 75. Rata-rata kelas yang didapatkan dari nilai tes individu yaitu hasil tes prasiklus 71,94 dan hasil tes siklus I 79,91. Melihat ratarata tersebut menunjukkan bahwa penelitian yang dilakukan pada siklus I telah dapat meningkatkan nilai meskipun belum sesuai target pencapaian yang diharapkan. Perbandingan hasil nilai prasiklus dan nilai siklus I dapat dilihat dengan tabel 3 di bawah ini. Berdasarkan tabel diatas dapat dilihat bahwa jumlah ketuntasan siswa dan jumlah siswa yang belum tuntas pada siklus I telah meningkat jika dibandingkan dengan prasiklus. Meski demikian, ketuntasan yang didapatkan belum memenuhi target harapan. Hal ini menunjukkan bahwa peneliti harus melanjutkan siklus II dengan harapan bahwa ketuntasan hasil belajar dapat meningkat sesuai harapan. 
Peningkatan Prestasi dan Motivasi Belajar PPKn Siswa Kelas VIII A SMP N 2

Gedangsari - Gunungkidul...(Ismiyati)

Tabel 3

Perbandingan Prestasi BelajarPrasiklus dan Siklus I

\begin{tabular}{|c|l|c|c|}
\hline No & Keterangan & Prasiklus & Siklus I \\
\hline 1 & Tuntas & $29,4 \%$ & $76,5 \%$ \\
\hline 2 & Tidak tuntas & $70,6 \%$ & $23,5 \%$ \\
\hline & jumlah & $100 \%$ & $100 \%$ \\
\hline
\end{tabular}

\section{Hasil siklus II}

Siklus II dilaksakan selama 2 pertemuan (6 jam pelajaran), yaitu pada hari Selasa tanggal 11 dan 18 November 2014 dengan menggunakan model pembelajaran kooperatif tipe Group Investigation. Materi yang disampaikan pada siklus II ini adalah Menjelajah Masyarakat Indonesia. Tes siklus II diberikan pada hari Selasa tanggal 25 November 2014 yang terdiri dari 5 soal yang berbentuk soal uraian dengan rata-rata kelas yang diperoleh siswa yaitu 89,59. Hasil tes siklus II dapat diketahui nilai tertinggi sebesar 100 dan nilai terendahnya 67. Jumlah siswa yang sudah mencapai kriteria ketuntasan minimal yaitu 32 siswa atau 94,1\% dari 34 siswa. Sedangkan siswa yang belum mencapai kriteria ketuntasan minimal berjumlah 2 siswa atau 5,9\% dari 28 siswa dengan nilai (KKM) kriteria ketuntasan minimal 75. Ketuntasan hasil tes siklus I dapat di lihat dari tabel 4 dibawah ini.

Tabel 4.

Ketuntasan Prestasi Belajar Siklus II

\begin{tabular}{|l|l|c|c|l|}
\hline No & Nilai & $\begin{array}{l}\text { Jumlah } \\
\text { Siswa }\end{array}$ & Persentase & Keterangan \\
\hline 1 & $<75$ & 2 & $5,9 \%$ & Tidak tuntas \\
\hline 2 & $\geq 75$ & 32 & $94,1 \%$ & Tuntas \\
\hline & JUMLAH & 32 & $100 \%$ & \\
\hline
\end{tabular}

Berdasarkan pengamatan lebih lanjut, diketahui bahwa rata-rata motivasi siswa dalam pembelajaran sebesar 41. Hal ini menunjukkan telah terjadinya peningkatan motivasi jika dibandingkan dengan siklus sebelumnya, yaitu 32.

Siswa sudah banyak yang tuntas pada siklus ini disebabkan oleh kerjasama siswa dalam kelompok sudah terlihat sehingga motivasi siswa yang kurang sudah terbentuk. Mereka belajar dengan siswa yang pintar, tanggung jawab kelompok sudah terbentuk untuk bersaing dengan kelompok yang lain. Siswa juga dalam menyampaikan hasil kerja kelompok sudah terlihat baik dan benar. Keaktifan siswa mulai nampak terlihat dengan pertanyaan-pertanyaan saat mengalami kesulitan, terjalin komunikasi yang baik di kelas. Akhir pertemuan 
siklus II diberikan soal tes uraian berjumlah 5, banyak siswa yang percaya diri mengerjakan soal dan sedikit ditemukan siswa yang berdiskusi dengan temannya.

\section{Perbandingan Siklus I dan Siklus II}

Berdasarkan refleksi siklus I, perlu dilakukan melanjutkan siklus II karena hasil tes siklus I belum memenuhi indikator kinerja penelitian yaitu $90 \%$ atau peningkatan yang terjadi belum sesuai harapan. Pelaksanaan siklus II menggunakan model pembelajaran kooperatif tipe Group Investigation dengan tujuan agar siswa lebih termotivasi dalam belajar dengan saling bekerja sama antar teman dan mereka dapat saling bertukar informasi, yang sudah bisa dapat mengajari temannya yang belum bisa sehingga ketika undian dilakukan sudah bisa. Kerja kelompok diharapkan mampu meningkatkan hasil belajar dan motivasi siswa pada materi Menjelajah Masyarakat Indonesia.

Pelaksanaan tes siklus I dan siklus II masih ditemukan hasil tes siswa yang belum mencapai kriteria ketuntasan minimal 75. Siklus I yang belum mencapai KKM berjumlah 8 siswa sedangkan pada siklus II sudah mulai menurun terlihat dari jumlah siswa yang belum mencapai nilai KKM sebanyak2 siswa. Perbandingan ketuntasan pada siklus I dan siklus II dapat terlihat pada tabel 5 dibawah ini

Tabel 5

Perbandingan Prestasi Belajar Siklus I dan Siklus II
\begin{tabular}{|l|l|c|c|}
\hline No & Keterangan & Siklus I & Siklus II \\
\hline 1 & Tuntas & $76,5 \%$ & $94,1 \%$ \\
\hline 2 & Tidak tuntas & $23,5 \%$ & $5,9 \%$ \\
\hline & Jumlah & $100 \%$ & $100 \%$ \\
\hline
\end{tabular}

Berdasarkan tabel diatas dapat dilihat bahwa jumlah ketuntasan siswa pada siklus II mengalami peningkatan.jumlah ketuntasan siswa pada siklus II (sebanyak 94,1\%) lebih banyak daripada siklus I (sebanyak 76,5\%). Sedangkan jumlah siswa yang belum mencapai ketuntasan menurun (dari $23,5 \%$ di siklus 1 menjadi 5,9\% di siklus 2). Hal ini menandakan bahwa siklus II sudah berhasil, peneliti sudah melampaui indikator kinerja penelitian ini yaitu $90 \%$ siswa tuntas KKM 75.

\section{Perbandingan Prasiklus, Siklus I, dan Siklus II}

Penelitian tindakan ini terdiri dari prasiklus dan 2 siklus. Kedua siklus ini merupakan kegiatan yang berkesinambungan yang artinya pelaksanaan siklus I berdasarkan refleksi dari prasiklus, dan siklus II merupakan lanjutan berdasarkan dari refleksi siklus I. Berdasarkan hasil belajar siswa pada saat diadakan tes 
Peningkatan Prestasi dan Motivasi Belajar PPKn Siswa Kelas VIII A SMP N 2

Gedangsari - Gunungkidul...(Ismiyati)

prasiklus ketuntasan hanya mencapai 10 siswa atau 29,4\% dari 34 siswa dan jumlah siswa yang belum mencapai ketuntasan sebanyak 24 siswa atau $70.6 \%$.

Setelah pembelajaran siklus I, hasil belajar dan motivasi belajar mengalami peningkatan yang cukup signifikan. Dari 34 siswa yang ada, sebanyak 26 siswa (76,5\%) sudah mengalami ketuntasan, dan sisanya 8 siswa atau 23,5\% siswa belum mengalami ketuntasan. Motivasi siswa juga mengalami peningkatan secara kasat mata. Sedangkan instrumen motivasi yang telah diisi menunjukkan nilai motivasi sebesar 32. Meski demikian, kondisi ini belum seperti harapan peneliti, yaitu ketuntasan yang mencapai $90 \%$.

Melihat kondisi ketuntasan pada siklus I dilakukan siklus II untuk perbaikan. Pada siklus II ketuntasan meningkat menjadi 32 siswa atau 94,1\%. Sedangkan siswa yang belum tuntas sebanyak 2 siswa atau 5,9\%. Motivasi siswa juga meningkat menjadi 41 secara rata-rata. Hasil siklus II dapat dijadikan kesimpulan bahwa penelitian tindakan kelas yang dilakukan peneliti berhasil, dengan hasil belajar siswa yang dapat dilihat pada tabel dibawah ini.

Tabel 6

Perbandingan Prestasi Belajar Prasiklus, Siklus I dan Siklus II

\begin{tabular}{|l|l|c|c|c|}
\hline No & Keterangan & Prasiklus & Siklus I & Siklus II \\
\hline 1 & Tuntas & $29,4 \%$ & $76,5 \%$ & $94,1 \%$ \\
\hline 2 & Tidak tuntas & $70,6 \%$ & $23,5 \%$ & $5,9 \%$ \\
\hline & Jumlah & $100 \%$ & $100 \%$ & $100 \%$ \\
\hline
\end{tabular}

\section{SIMPULAN DAN SARAN}

Setelah dilakukan Penelitian Tindakan Kelas yang berjudul Upaya Meningkatkan Prestasi Belajar dan Motivasi Belajar PPKn Siswa Melalui Model Pembelajaran Group Investigation di Kelas VIII A SMP Negeri 2 Gedangsari, Kabupaten Gunungkidul 2014 dapat disimpulkan beberapa hal. Simpulan ini merupakan jawaban dari rumusan masalah yang telah dikemukakan di bab I sebagai berikut.

- Penggunaan model Group Investigation dapat meningkatkan prestasi belajar PPKn siswa kelas VIII A SMP Negeri 2 Gedangsari, Gunungkidul.

- Penggunaan model Group Investigation dapat meningkatkan motivasi belajar PPKn siswa kelas VIII A SMP Negeri 2 Gedangsari, Gunungkidul. Dengan meningkatnya prestasi belajar dan motivasi belajar siswa dalam

mata pelajaran PPKn, maka dapat disarankan beberapa hal yang terkait dengan manfaat penelitian sebagai berikut.

- Bagi siswa, disarankan untuk belajar secara berkelompok sesuai dengan prinsip pembelajaran kooperatif, dimana hasil pemikiran dari 2 otak akan lebih baik dibanding 1, apalagi banyak otak. Secara teknis, cara belajar 
secara berkelompok dapat mengikuti sintak dari pembelajaran kooperatif tipe Group Investigation yang telah diteliti ini. Hal ini dapat dilakukan baik di dalam kelas (ketika pembelajaran bebas atau jam kosong), maupun di luar kelas (ketika akan melaksanakan pembelajaran mandiri).

- Bagi guru, disarankan untuk menggunakan model pembelajaran Group Investigation ini ketika akan mengajar pelajaran PPKn, khususnya pada materi disiplin itu indah dan menjelajah masyarakat Indonesia.

- Bagi sekolah/lembaga pendidikan disarankan untuk mengarahkan gurugurunya supaya menggunakan model pembelajaran kooperatif tipe Group Investigation ini jika tujuannya adalah meningkatkan prestasi belajar dan motivasi belajar.

- Selain itu disarankan untuk diadakan penelitian lanjutan mengenai penerapan model pembelajaran Group Investigation untuk mata pelajaran lain, kelas lain, sekolah lain, maupun untuk tujuan lain selain meningkatkan prestasi belajar dan motivasi belajar (misalnya untuk tujuan meningkatkan keaktifan siswa, kedisiplinan siswa, kerja sama, dan variabel-variabel dampak yang lain).

\section{DAFTAR PUSTAKA}

Djamarah, B.S. 2008. Psikologi Belajar. Jakarta: Rineka Cipta

Gulo, W. 2008. Strategi Belajar Mengajar. Jakarta: Grasindo

Hakim T. 2005.Belajar Secara Efektif. Jakarta: Puspa Swara

Hamalik, O. 2011. Proses Belajar Mengajar. Jakarta: Bumi Aksara

Heywood, J. 2000. Assessment in Higher Education: Student Learning Teaching Programes and Institutions. Lodon: Jessica Kingsley Publisher Ltd

Nizar, A. H. 2008. Classroom Action Research. Jakarta: Rahayasa

Purwanto. 2011. Evaluasi Hasil Belajar. Yogyakarta: Pustaka Pelajar

Santrock, W.J. 2003. Adolescence. Perkembangan Remaja. Jakarta: Erlangga

Sardiman, A.M. 2011. Interaksi \& Motivasi Belajar. Jakarta: Rajawali Press

Satmoko, R.S. 1999. Proses Belajar Mengajar II: Penilaian Hasil Belajar. Semarang: IKIP Semarang Press

Situmorang, R., Suparman, A., Susilana, R. 2004. Desain Pembelajaran. Jakarta: Universitas Terbuka

Slameto. 2010. Belajar dan Faktor-faktor yang Mempengaruhi. Jakarta: Rineka Cipta

Sudjana, N. 2003. Penilaian Hasil Proses Belajar Mengajar. Bandung: Remaja Rosdakarya 
Peningkatan Prestasi dan Motivasi Belajar PPKn Siswa Kelas VIII A SMP N 2

Gedangsari - Gunungkidul...(Ismiyati)

Sukmadinata, S.N. 2005. Landasan Psikologi Proses Pendidikan. Bandung: Remaja Rosdakarya

Syah, M. 2008. Psikologi Pendidikan dengan Pendekatan Baru. Bandung: Remaja Rosdakarya.

Tafsir, A. 2008. Strategi Meningkatkan Mutu Pendidikan Agama Islam di Sekolah. Bandung: Maestro

Taniredja, T., Pujiati, I., Nyata. 2011. Penelitian Tindakan Kelas. Bandung: Alfabeta

Trianto. 2007. Mendesain Model Pembelajaran Inovatif-Progresif. Jakarta: Kencana

UU No. 20 Tahun 2003 Tentang Sistem Pendidikan Nasional

Wibowo, B., Priyono, B. H. 2006. Sesudah filsafat: Esai-esai untuk Franz Magnis-Suseno. Yogyakarta: Kanisius 